\title{
The Relationship Of Drinking Tea Behavior With Levels Of Hemoglobin in STIKes Guna Bangsa Yogyakarta Students
}

\section{Hubungan Perilaku Minum Teh Dengan Kadar Hemoglobin Pada Mahasiswa STIKes Guna Bangsa Yogyakarta}

Relita Pebrina, Ikrimah Nafilata, Sunartono Sunartono dan Fransiska Aselina

\begin{abstract}
Iron has an important role in the body that functions to transport oxygen from the lungs to all body tissues through hemoglobin in the blood. Iron deficiency is one of the factors causing anemia. Anemia can be diagnosed from a level of hemoglobin. If a person's has $\mathrm{Hb}$ level is low, it can be said that the person is suffering from anemia. The low $\mathrm{Hb}$ level can be influenced by several factors, one of which is the consumption of tea. The content of tannins in tea can reduce iron absorption by the body. This study aims to analyze the relationship between drinking of tea behavior in STIKES Guna Bangsa Yogyakarta students with level of hemoglobin. The method is carried out by direct interviews with 55 samples of female students and level of henoglobin were checked using the $\mathrm{Hb}$ meter automatic. The results obtained were that $71 \%$ of the samples consumed tea and $29 \%$ did not consume tea. $53.85 \%$ of the sample who consumed tea had a low $\mathrm{Hb}$ level whereas $68.75 \%$ of the samples that did not consume tea had normal $\mathrm{Hb}$ levels. Data from the results of chi-square analysis obtained a value of $p=0.001<0.05$, which means that there is a relationship between the behavior of tea drinking with hemoglobin levels in STIKES students for Yogyakarta
\end{abstract}

Keywords: tea consumption, hemoglobin level

Afiliasi Penulis

Prodi D3 Teknologi Transfusi Darah STIKes Guna Bangsa

Yogyakarta

Korespondensi kepada

R. Pebrina

relita.cordova@gmail.com 


\section{Intisari}

Zat besi memiliki peranan penting dalam tubuh yang berfungsi untuk mengangkut oksigen dari paruparu ke seluruh jaringan tubuh melalui hemoglobin dalam darah. Defisiensi zat besi merupakan salah satu faktor penyebab anemia. Anemia dapat didiagnosa dari kadar $\mathrm{Hb}$ seseorang. Apabila kadar $\mathrm{Hb}$ seseorang rendah maka dapat dikatakan orang tersebut menderita anemia. Rendahnya kadar $\mathrm{Hb}$ dapat dipengaruhi oleh beberapa faktor, salah satunya adalah konsumsi teh. Kandungan tanin dalam teh dapat mengurangi penyerapan zat besi oleh tubuh. Penelitian ini bertujuan untuk menganalisis hubungan antara perilaku minum teh pada mahasiswa STIKES Guna Bangsa Yogyakarta dengan kadar $\mathrm{Hb}$. Metode yang dilakukan dengan wawancara langsung terhadap 55 sampel mahasiswa yang berjenis kelamin perempuan dan dilakukan pengecekan kadar $\mathrm{Hb}$ menggunakan $\mathrm{Hb}$ meter automatic. Hasil yang didapat bahwa sebanyak $71 \%$ sampel mengkonsumsi teh dan $29 \%$ tidak mengkonsumsi teh. 53,85\% sampel yang mengkonsumsi teh memiliki kadar $\mathrm{Hb}$ rendah sedangkan $68,75 \%$ sampel yang tidak mengkonsumsi teh memiliki kadar $\mathrm{Hb}$ normal. Data hasil hasil analisis chi square diperoleh nilai $\mathrm{p}=$ $0,001<0,05$, yang berarti bahwa terdapat hubungan antara perilaku minum teh dengan kadar Hemoglobin pada mahasiswa STIKES Guna Bangsa Yogyakarta.

Kata Kunci : Konsumsi Teh, Kadar Hb

\section{Pendahuluan}

Zat besi memiliki peranan penting dalam tubuh. Zat besi berfungsi untuk mengangkut oksigen dari paru-paru ke seluruh jaringan tubuh oleh Hemoglobin dalam sel darah merah (1). Struktur Hemoglobin terdiri atas Heme yang merupakan empat atom besi dalam bentuk $\mathrm{Fe}^{2+}$ yang dikelilingi oleh cincin protoporfirin IX dan Globin yang terdiri dari asam amino yang membentuk rantai polipeptida (2). Zat besi berkaitan erat dengan anemia. Salah satu faktor penyebab anemia adalah defisiensi zat besi. Anakanak, wanita hamil, dan wanita pospartum membutuhkan zat besi yang tinggi sehingga rentan mengalami anemia. Sekitar $20 \%$ dari kematian perinatal dan $10 \%$ dari kematian ibu di negara berkembang disebabkan oleh defisiensi zat besi. Secara total, kematian di seluruh dunia sebanyak $1,3 \%$ pada pria dan $1,8 \%$ pada wanita disebabkan oleh defisiensi zat besi. Selain itu, anemia defisiensi besi pada anak usia dini dapat mengurangi kecerdasan bahkan dapat menyebabkan keterbelakangan mental ringan (3).

Secara nasional, proporsi anemia penduduk $\geq 1$ tahun sebanyak $21,7 \%$, balita (12-59 bulan) sebanyak $28,1 \%$, dan ibu hamil sebanyak $37,1 \%$ (4). Sudikno dan Sandjaja melaporkan prevalensi anemia pada Wanita Usia Subur (WUS) sebesar $9,6 \%$ (5). Kaimudin, et al melaporkan bahwa proporsi penderita anemia pada remaja putri SMA Negeri 3 Kendari tahun 2017 sebanyak 41,7\% (6).

Anemia disebabkan oleh beberapa faktor di antaranya yaitu kehilangan banyak darah akibat menstruasi, infeksi parasit, dan menurunnya kadar hemoglobin dalam darah (7). Kadar Hemoglobin $(\mathrm{Hb})$ juga berkaitan dengan syarat seseorang untuk dapat mendonorkan darahnya. Seseorang dapat mendonorkan darah apabila kadar $\mathrm{Hb}$ berkisar antara 12,5-17 g/dL (8). Kualitas darah yang akan ditransfusikan harus terjamin kualitasnya sehingga apabila kadar $\mathrm{Hb}$ dari darah calon pendonor di bawah ambang batas maka akan mengganggu kualitas darah yang akan ditransfusikan. dapat dipengaruhi oleh beberapa faktor di antaranya gaya hidup, asupan nutrisi, dan konsumsi makanan atau minuman yang dapat mempengaruhi penyerapan zat besi oleh tubuh.

Studi klinis yang dilakukan pada seorang pria berusia 48 tahun dengan diagnosis hipertensi, Diabetes Melitus (DM) Tipe 2, dan thalasemia tingkat rendah didapatkan bahwa pasien tersebut memiliki kadar $\mathrm{Hb}$ rendah. Pemeriksaan gastroskopi dan kolonoskopi menunjukkan tidak ada sumber perdarahan yang signifikan yang menyebabkan kadar $\mathrm{Hb}$ pada pasien tersebut rendah hingga didapatkan bahwa kemungkinan 
defisiensi besi disebabkan karena kebiasaan minum teh hijau. Perawatan dilakukan dengan pemberian injeksi intravena sebanyak $400 \mathrm{mg}$ zat besi dalam bentuk kompleks sukrosa besi hidroksida selama 1 kali dalam seminggu dan pasien dianjurkan untuk berhenti mengkonsumsi teh. Suplemen zat besi oral diberikan pada pasien saat pasien berhenti mengkonsumsi teh hijau dan didapati kadar $\mathrm{Hb}$ mulai meningkat. Setelah 2 bulan pengobatan dan kadar $\mathrm{Hb}$ telah mencapai 11,2 $\mathrm{g} / \mathrm{dL}$, pasien kembali pada kebiasaannya minum teh hijau dan hal ini menyebabkan penurunan kadar $\mathrm{Hb}$ kembali pada pasien tersebut. Injeksi intravena diberikan kembali dengan interval 2-3 minggu untuk meningkatkan kadar $\mathrm{Hb}$ dan didapatkan kadar $\mathrm{Hb}$ meningkat (9).

Penurunan kadar $\mathrm{Hb}$ ditunjukkan pada 20 orang yang diberi perlakuan konsumsi teh hijau sebanyak $300 \mathrm{ml} /$ hari selama 30 hari dan didapatkan nilai kadar $\mathrm{Hb}$ menurun dari 12,58 g/dL menjadi 11,76 $\mathrm{g} / \mathrm{dL}$ setelah konsumsi teh hijau selama 30 hari (10). Prevalensi Iron Deficiency Anemia (IDA) berdasarkan jenis kelamin yaitu pada pria sebesar $46 \%$, wanita $54 \%$. Prevalensi IDA berdasarkan usia yaitu pada usia usia 17-19 tahun sebesar $25 \%$, usia 20-22 tahun sebesar 50,2\%, dan usia 23-25 tahun sebesar $15,08 \%$. Dari penelitian yang dilakukan didapatkan bahwa sarapan teratur memiliki peran signifikan mencegah IDA, selain itu konsumsi sayuran/buah, dan perilaku minum teh berperan penting dalam prevalensi IDA (11).

Perilaku minum teh berperan dalam defisiensi zat besi yang dapat menyebabkan anemia. Perilaku minum teh telah menjadi kebiasaan dalam kehidupan sehari-hari termasuk pada mahasiswa STIKES Guna Bangsa Yogyakarta. Penelitian ini dilakukan untuk mengetahui hubungan antara perilaku minum teh dengan kadar $\mathrm{Hb}$ pada mahasiswa STIKES Guna Bangsa Yogyakarta.

\section{Metode}

Penelitian ini merupakan penelitian
Observasional analitik dengan desain Cross
Sectional, menggunakan metode survei melalui
dua tahap, yaitu pemeriksaan sampel darah pada
mahasiswa STIKES Guna Bangsa Yogyakarta yang
berusia 18-23 tahun, jenis kelamin perempuan,
berat badan 40-65 kg, dan tidak sedang hamil atau

menyusui untuk kemudian dicek kadar $\mathrm{Hb}$ menggunakan alat $\mathrm{Hb}$ meter automatic. Metode survei yang kedua yaitu wawancara terstruktur beserta observasi langsung. Lokasi penelitian di STIKES Guna Bangsa Yogyakarta.

Sampel diambil secara purposif dengan besar sampel minimal sebesar 30 sampel, sampel di lapangan dalam penelitian ini sebanyak 55 sampel mahasiswa STIKES Guna Bangsa yang sesuai dengan kriteria inklusi. Penelitian dilakukan pada Bulan Juli 2018.

Analisis data yang digunakan adalah analisis bivariat untuk mengetahui hubungan antara variabel bebas (perilaku minum teh) dengan variabel terikat (kadar $\mathrm{Hb}$ ) dan uji Chi Square dengan tingkat kepercayaan 95\%.

\section{Hasil \& Pembahasan}

Karakteristik sampel dalam penelitian ini adalah semua mahasiswa STIKES Guna Bangsa Yogyakarta yang datang minum teh di kantin, meliputi: umur, status minum teh, dan kadar hemoglobin.

Analisis data yang digunakan adalah analisis deskriptif untuk mendeskripsikan distribusi frekuensi, persentase dari karakteristik responden dan untuk menganalisis variabel terikat serta variabel bebas. Dari hasil distribusi frekuensi kelompok umur sampel didapatkan bahwa mayoritas umur sampel adalah pada usia 20-23 tahun yaitu sebesar $73 \%$ (40 orang) dan kelompok umur 18-19 tahun sebesar 27\% (15 orang). Berdasarkan data hasil wawancara didapatkan bahwa dari 55 orang sampel, sebanyak $71 \%$ mengkonsumsi teh dan $29 \%$ tidak mengkonsumsi teh. 


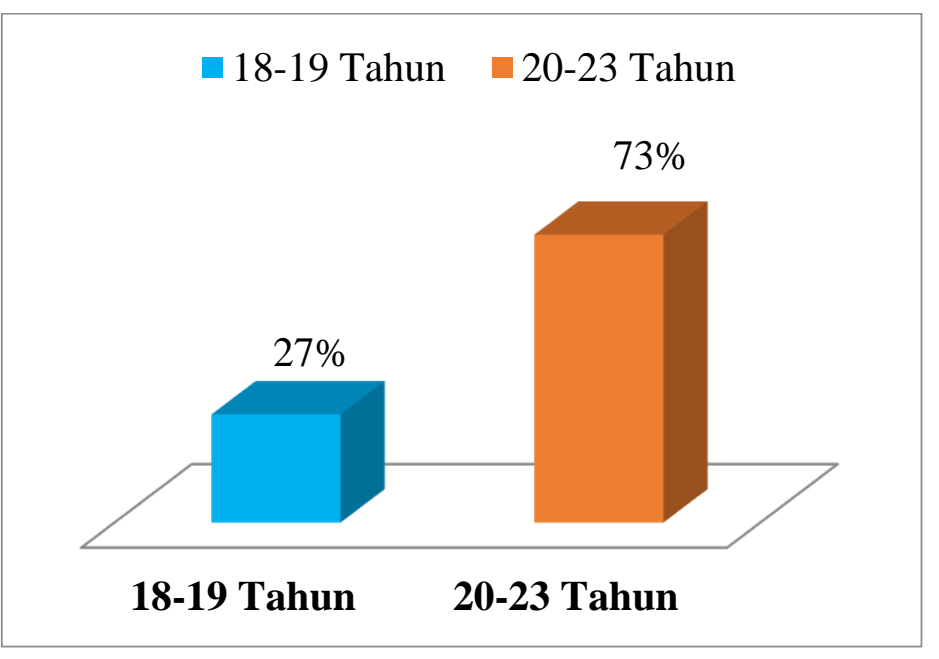

Gambar 1 | Distribusi Frekuensi Kelompok Umur Sampel dan Frekuensi Status Konsumsi Teh

Data hasil pengukuran kadar $\mathrm{Hb}$ pada sampel yang mengkonsumsi teh dan tidak mengkonsumsi teh dikategorikan menjadi rendah, normal, dan tinggi. Kadar $\mathrm{Hb}$ rendah apabila kadar $\mathrm{Hb}$ sampel $<12,5 \mathrm{~g} / \mathrm{dL}$, normal apabila kadar Hb sampel 12,5 $\mathrm{g} / \mathrm{dL}$, dan tinggi apabila kadar Hb sampel $>14,5$ $\mathrm{g} / \mathrm{dL}$. Hasil yang didapat pada sampel yang mengkonsumsi teh yaitu kadar $\mathrm{Hb}$ rendah sebesar $53,85 \%$, kadar $\mathrm{Hb}$ normal sebesar $38,46 \%$, dan kadar $\mathrm{Hb}$ tinggi sebesar $7,69 \%$, sedangkan pada sampel yang tidak mengkonsumsi teh didapatkan kadar $\mathrm{Hb}$ rendah sebesar $12,5 \%$, kadar $\mathrm{Hb}$ normal sebesar 68,75\%, dan kadar $\mathrm{Hb}$ tinggi sebesar $18,75 \%$. Hal ini menunjukkan bahwa pada sampel yang mengkonsumsi teh memiliki persentase kadar
$\mathrm{Hb}$ rendah yang cukup tinggi dan pada sampel yang tidak mengkonsumsi teh, persentase sampel dengan kadar $\mathrm{Hb}$ normal cukup tinggi.

Berdasarkan hasil analisis chi square diperoleh nilai $p=0,001<0,05$, yang berarti bahwa terdapat hubungan antara perilaku minum teh dengan kadar Hemoglobin pada mahasiswa STIKES Guna Bangsa Yogyakarta. Hal ini bersesuaian dengan penelitian terhadap 20 sampel yang diberi perlakuan minum teh hijau sebanyak $300 \mathrm{ml} /$ hari selama 30 hari dan didapati bahwa kadar $\mathrm{Hb}$ menurun selama kurun waktu tersebut (10).

Teh hitam dapat menghambat penyerapan zat besi sebesar $79-94 \%$ jika dikonsumsi bersama-sama dengan makanan yang banyak mengandung zat

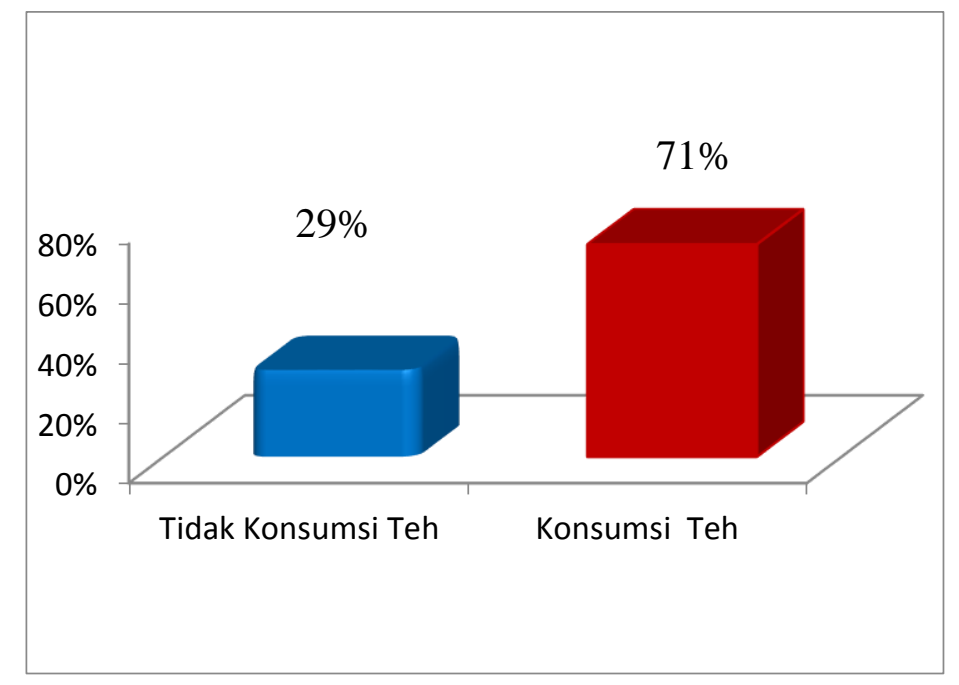

Gambar 2 | Distribusi Frekuensi Status Konsumsi Teh 


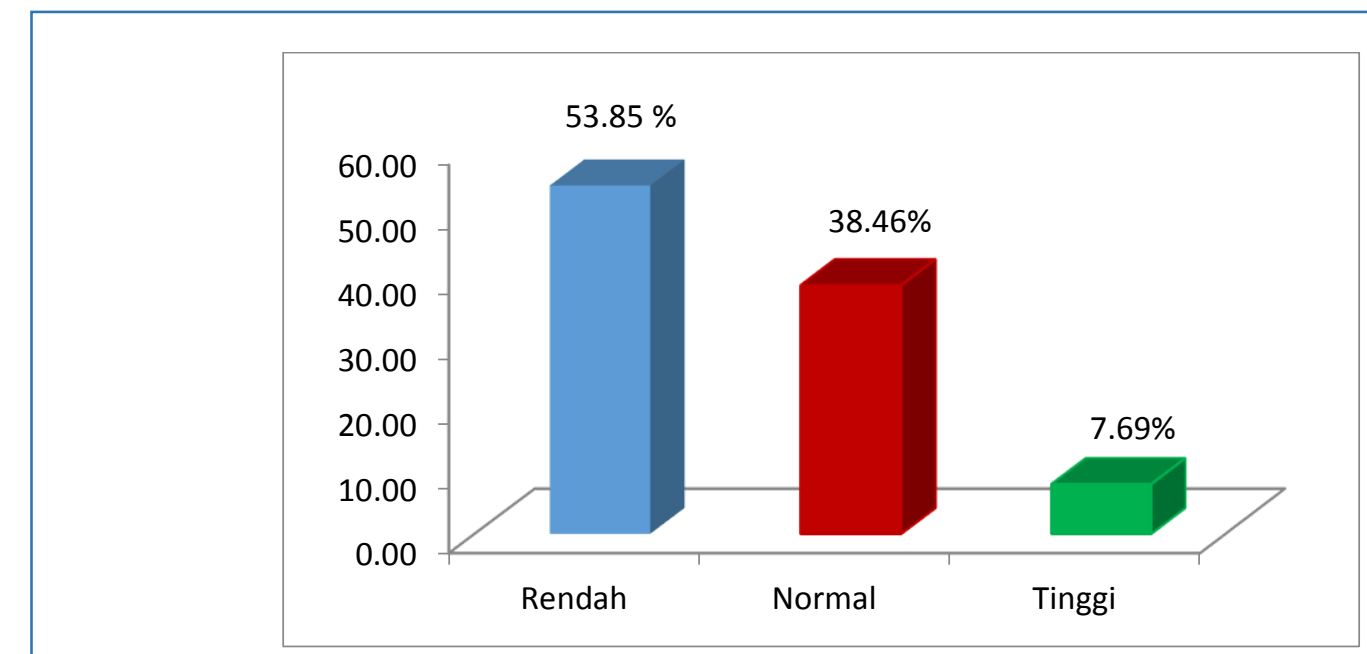

Gambar 3 | Distribusi Frekuensi Kategori Kadar Hb pada Responden yang Mengkonsumsi Teh

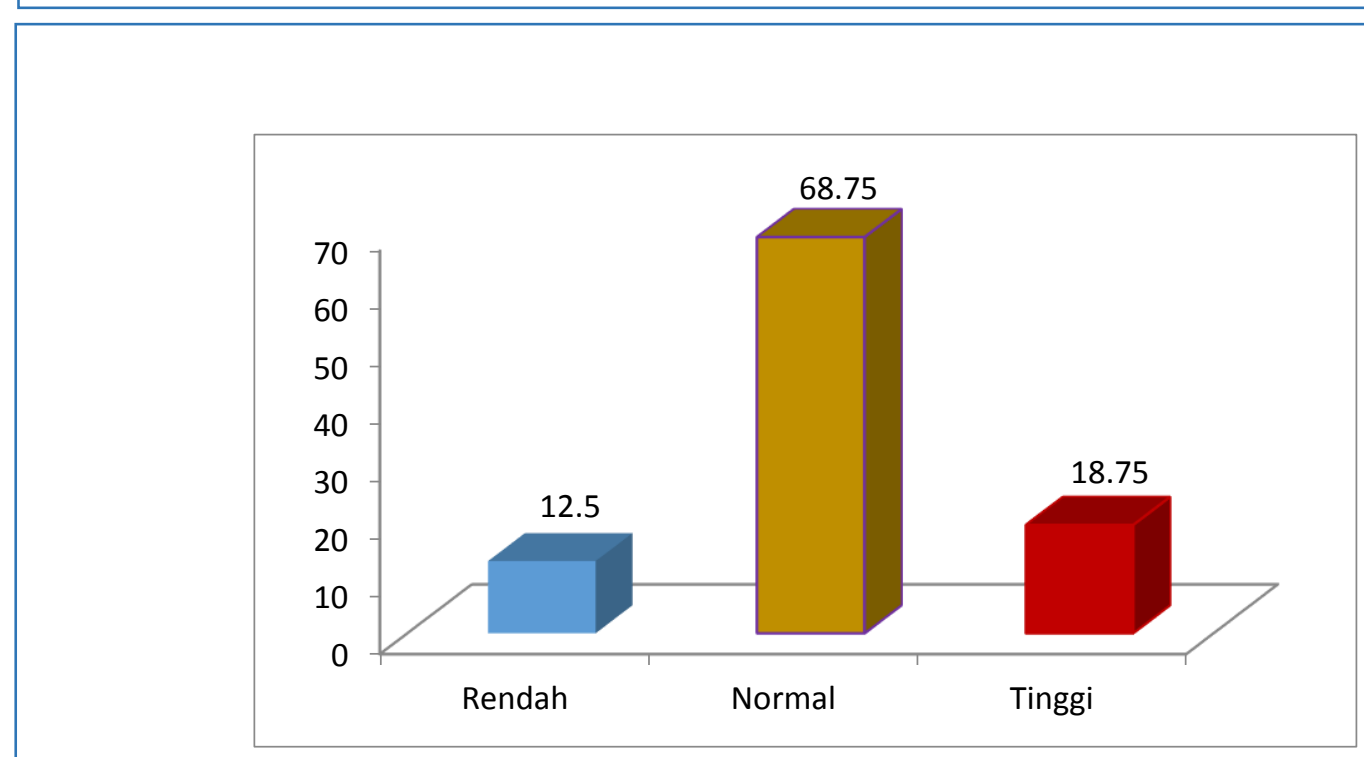

Gambar 4 | Distribusi Frekuensi Kategori Kadar Hb pada Responden yang Tidak Mengkonsumsi Teh

besi dan kalsium yang sulit diserap tubuh sehingga menyebabkan penurunan zat besi (Fe) (12). Saat teh direaksikan dengan zat besi akan menyebabkan reaksi pengelatan yaitu reaksi koordinasi antara molekul logam dengan molekul organik yang memiliki sepasang elektron bebas di tiap ujungnya sehingga molekul organik akan berikatan dengan molekul logam. Dalam hal ini, zat besi akan membentuk kelat dengan molekul organik dari teh yaitu polifenol yang terkandung dalam teh sehingga menyebabkan berkurangnya konsentrasi zat besi yang dapat diserap oleh tubuh (13).

\section{Kesimpulan}

Berdasarkan hasil penelitian, didapatkan bahwa $71 \%$ sampel mengkonsumsi teh dan $29 \%$ tidak mengkonsumsi teh. $53,85 \%$ sampel yang mengkonsumsi the memiliki kadar $\mathrm{Hb}$ rendah sedangkan $68,75 \%$ sampel yang tidak mengkonsumsi the memiliki kadar $\mathrm{Hb}$ normal. $\mathrm{Hal}$ ini menunjukkan bahwa sebagian besar sampel yang mengkonsumsi teh memiliki kadar $\mathrm{Hb}$ yang rendah. Data hasil hasil analisis chi square diperoleh nilai $p=0,001<0,05$, yang berarti bahwa terdapat hubungan antara perilaku minum teh dengan kadar Hemoglobin pada mahasiswa STIKES Guna Bangsa Yogyakarta. 


\section{Bibliografi}

1. Thompson B. Food-based approaches for combating iron deficiency. Nutr Anemia. 2007;337-58.

2. Kiswari R. Hematology dan Transfusi. Carolina S, Astikawati R, editors. Jakarta; 2014.

3. WHO. The World Health Organization Report 2002: reducing risks, promoting healthy life. WHO Libr Cat Publ Data. 2002;232.

4. Badan Penelitian dan Pengembangan Kesehatan., 2013, Riset Kesehatan Dasar, Kementerian Kesehatan Republik Indonesia, Jakarta

5. Sudikno S. Prevalensi dan Faktor Risiko Anemia pada Wanita Usia Subur di Rumah Tangga Miskin di Kabupaten Tasikmalaya dan Ciamis Provinsi Jawa BArat. J Kesehat Reproduksi [Internet]. 2016;7(April):71-82. Available from: http://ejournal.litbang.depkes.go.id/index.php/kespro/ article/viewFile/5438/4474

6. Skrining Dan Determinan Kejadian Anemia Pada Remaja Putri Sma Negeri 3 Kendari Tahun 2017. J IIm Mhs Kesehat Masy Unsyiah. 2017;2(6):1-10.

7. World Health Organization. Worldwide prevalence of anaemia: WHO Global Database on Anaemia. WHO Glob Database Anaemia [Internet]. 2005;1-51. Available from: http://whqlibdoc.who.int/publications/ 2008/9789241596657_eng.pdf

8. Peraturan Menteri Kesehatan Republik Indonesia Nomor 91 Tahun 2015, Standar Pelayanan Transfusi Darah, 31 Desember 2015, Jakarta

9. Fan FS. Iron deficiency anemia due to excessive green tea drinking. Clin Case Reports. 2016;4(11):1053-6.

10. Sachdev NA, Jothipriya M. Effect of Green Tea on Haemoglobin. IOSR J Dent Med Sci. 2017;16(05):116-8.

11. Al-Alimi AA, Bashanfer $S$, Morish MA. Prevalence of Iron Deficiency Anemia among University Students in Hodeida Province, Yemen. Anemia. 2018;2018.

12. Hurrell RF, Reddy M, Cook JD. Inhibition of non-haem iron absorption in man by polyphenolic-containing beverages. Br J Nutr. 1999;81(4):289-95.

13. Hallberg L, Hulthén L. Prediction of dietary iron absorption: An algorithm for calculating absorption and bioavailability of dietary iron. Am J Clin Nutr. 2000;71(5):1147-60. 